\title{
Aortic Dissection - The Role of Echocardiography in Emergency Unit: Case Report
}

\author{
Sanja Stojanović ${ }^{1}$, Marina Deljanin Ilićc ${ }^{1,2}$, Stevan Ilić1,2, Bojan Ilić ${ }^{1}$, \\ Milovan Stojanović ${ }^{1}$, Dejan Petrović1, \\ ${ }^{1}$ Institute for Treatment and Rehabilitation, Niška Banja, Niš, Serbia \\ ${ }^{2}$ Universyty of Niš, Faculty of Medicine, Niš, Serbia
}

\begin{abstract}
SUMMARY
Aortic dissection is a quite rare but serious condition, often associated with a very high mortality rate; it is manifested by sudden chest pain and acute hemodynamic compromise. In the presented review, a case of an ascending aortic dissection with the lethal outcome is been shown. A healthy man with no past history of illness suddenly felt acute excruciating chest pain which was radiating to the back. A quick diagnosis, ideally within one hour of manifestation, heart auscultation and echocardiography are the key to aortic dissection recovery.
\end{abstract}

Key words: acute aortic syndromes, aortic dissection, chest pain 


\section{INTRODUCTION}

Aortic dissection (AD) is the most frequent form of acute aortic syndrome and a serious condition that requires immediate medical and surgical care $(1,2)$ (Figure 1).

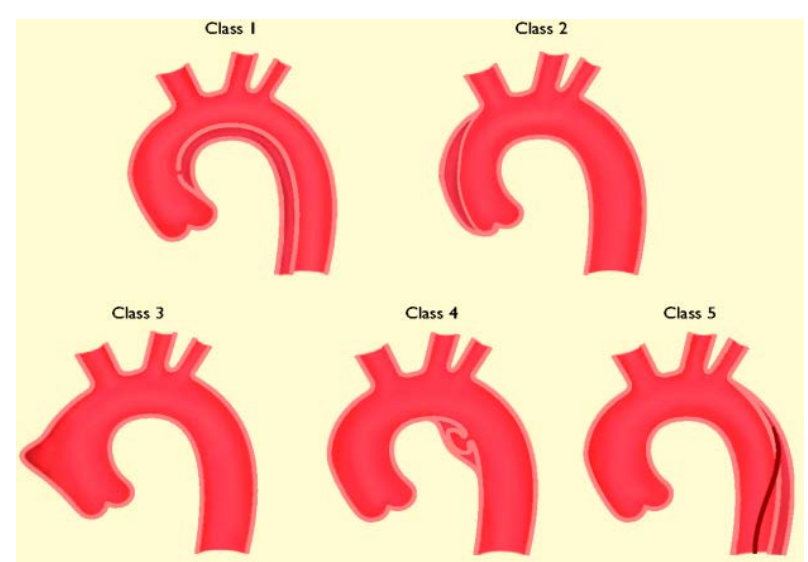

Figure 1. Classification of acute aortic syndrome in aortic dissection (2)

Aortic dissection is defined as disruption of the medial layer provoked by intramural bleeding, resulting in separation of the aortic wall layers and subsequent formation of a true lumen and a false lumen with or without communication (2). The initial rupture of the intima usually appears right above the valvulae or distal to the left subclavian artery. The pulsing extravasation of blood in the wall leads to progressive separation of the intima, mostly in the distal dissection. The consequent false lumen occupies at least one half of range and lumen of the true lumen.

DeBakey's division of AD describes three various types: type I involves the ascending part, arch and descending thoracic segment, dissection often extends to the abdominal aorta; type II involves the ascending aorta only; type III is further divided into two subtypes: type III A, starting distally from the left subclavian artery and finishing above the diaphragm and type III B, starting at the same point, but extending to the abdominal aorta. In the Stanford classification, type A dissections involve the ascending aorta, and type $\mathrm{B}$ dissections are those that do not involve the ascending aorta. Ascending dissections require emergency surgical repair, whereas medical therapy is usually the initial strategy for acute type B dissections (3) (Figure 2).

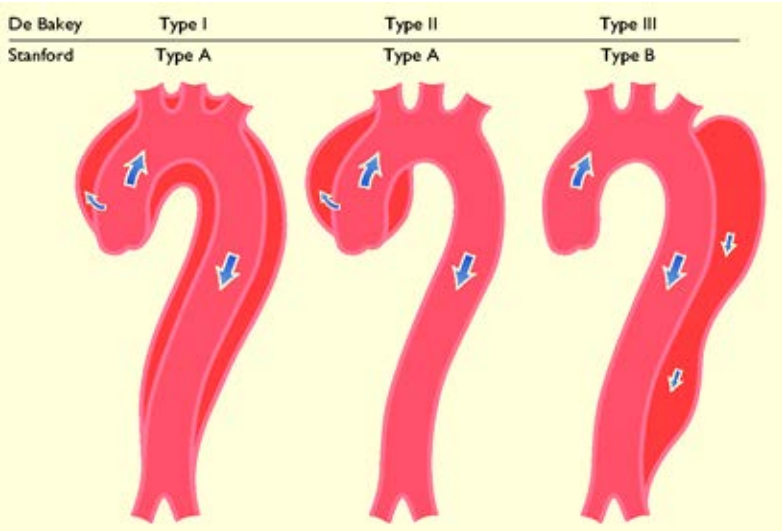

Figure 2. Classification of aortic dissection localization (4)

The etiology for aortic dissection is unknown; the most common cause is hypertension (80\%), atherosclerosis, connective tissue disorders such as Marfan syndrome, Ehlers-Danlos syndrome and bicuspid aortic valve disease. Other conditions include: infection, inflammation, trauma, and idiopathy. The Marfan syndrome is caused by mutation in one of the genes for fibrillin-1, which is the major component of elastin, with the prevalence of 1:5000. Ehlers-Danlos syndrome is a genetic disorder caused by the structure and production of collagen, and it manifests as aortic aneurysm, articular hypermobility, and tissue fragility $(4,5)$.

The methods of choice for the aortic dissection are echocardiography, transthoracic echocardiography, computerized tomography (CT), magnetic resonance imaging (MRI), aortography and coronary angiography. Echocardiography is a non-invasive method which is considered to be the diagnostic gold standard. Transthoracic echocardiography is an excellent initial diagnostic procedure to diagnose rapidly acute aortic dissection. The extension of the dissection for chronic dissection and hemodynamically stable patients can be shown by non-invasive methods such as CT and MRI. Although aortography and coronary angiography are the procedures that can be used in stable patients, they are often unavailable or inconclusive (6-8).

An echocardiographic sign of aortic dissection are the intimal flap, and mobile, linear echo, which divides the true lumen from the false lumen, with the presence of normal blood flow through the true lumen. In acute dissection, Ao intimal flap is quite mobile, 
motions follow the heart activity rhythm and the false lumen is more often larger than the true one, whereas the flap moves towards the false lumen. Visualization of the intimal flap by ultrasound may carry a sensitivity of $67-80 \%$ and specificity of $99-100 \%$ for dissection (8).

\section{CASE REPORT}

A sixty-nine years old, healthy man with no past history of illness suddenly felt acute excruciating chest pain which was radiating to his back. He was admitted at the Institute "Niska Banja" on $18^{\text {th }}$ of June, 2014. The patient's past medical history included long-term smoking (over 50 years) and heredity (father suddenly died of the heart attack). Initial vital signs included blood pressure of $95 / 60 \mathrm{mmHg}$ bilaterally and heart rate of 68 beats/minute. The physical examination revealed aortic murmur of regurgitation best heard in the aortic area. Repeatedly performed electrocardiograms showed sinus rhythm and nonspecific ST-T wave changes.

Electrocardiogram on admission to the coronary unit at the Institute is shown in Figure 3.

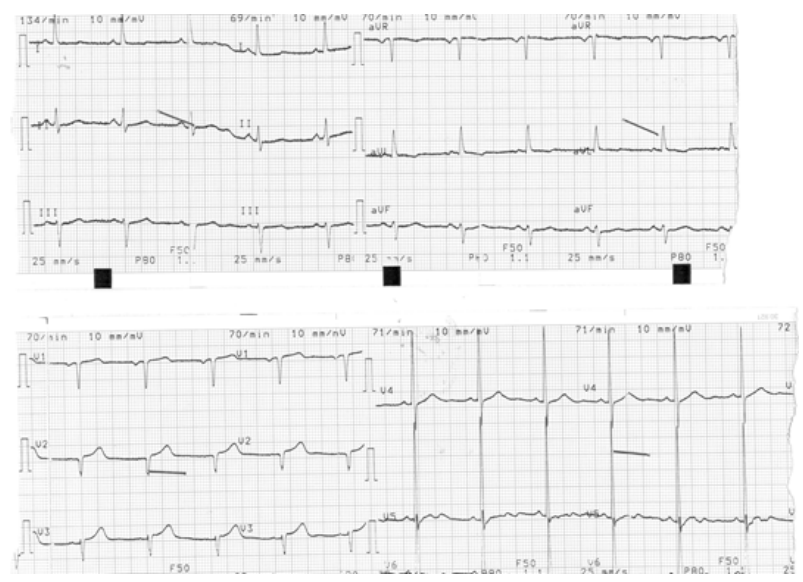

Figure 3. Electrocardiogram on admission to the coronary unit at the Institute

Laboratory studies show normal values for cholesterol, triglycerides, glycaemia, heart and liver enzymes, electrolytes and complete blood count. Thereafter, transthoracic echocardiography was performed and the results showed aortic dissection along the arch wall from the aortic root to the truncusbrachiocephalicus, with the presence of a false lumen (diameter $60 \mathrm{~mm}$ ) with severe aortic and tricuspid regurgitation, with left ventricular systolic function (EF 55\%) and normal kinetic walls of the left ventricle (Figure 4).
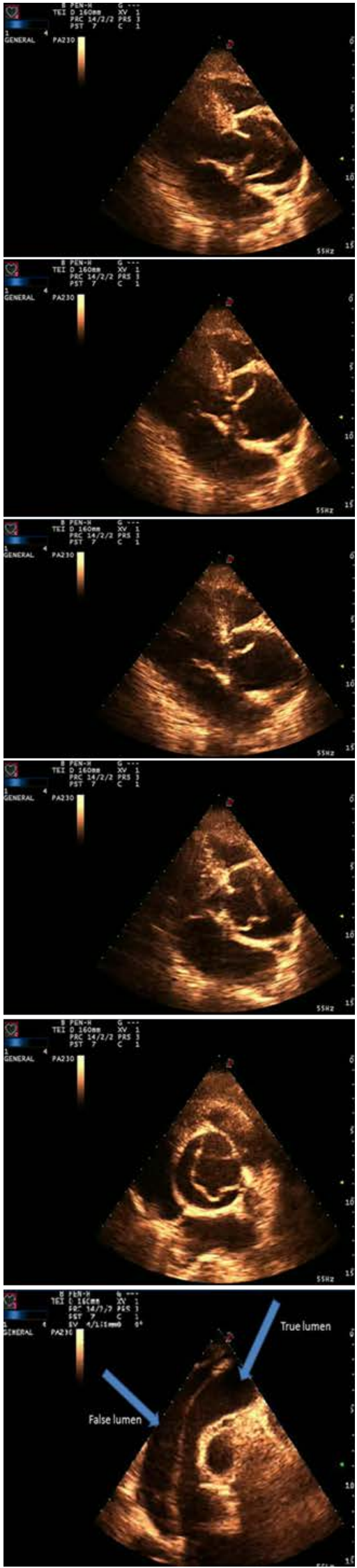

Figure 4. Intimal flap and false and true lumen in a patient with acute type A aortic dissection 
Cardiovascular surgeon was contacted immediately and the patient was transported in an ambulance with paramedics to the Institute for Cardiovascular Diseases "Dedinje". Unfortunately, the patient died on admission to the Cardiac Surgery Center due to progression of the course of the disease.

\section{DISCUSSION}

Aorta is the largest artery in the human body that carries oxygenated blood from the left ventricle of the heart to the rest of the body (9). In this regard, the rate of aortic expansion is about $0.9 \mathrm{~mm}$ in men and $0.7 \mathrm{~mm}$ in women for each decade of life. In the ascendant part, the aorta relatively lacks the external support, and it also bears the largest pressure during the heart cycle (10).

So far, the epidemiologic data on $\mathrm{AD}$ are quite poor. The data show that the frequency of $\mathrm{AD}$ is twice as more frequent in men aged 40-70 than in women, and its annual incidence rate is six per hundred thousand persons (10-12).

There are several different types of classification for thoracic aortic dissection. The most commonly used is the Stanford Classification. Our patient had type A dissection with two lumina identified from the aortic valve area (4).

Aortic dissection is a serious condition, the first and only sign of which is sudden coronary death which needs both rapid diagnosis and decision making to reduce the extremely poor prognosis. When left untreated, in the first 24 to 48 hours, mortality rate is very high, about to $1-2 \%$ (11). The most common symptoms are the chest pain $(80 \%)$, back and abdominal pain ( $40 \%$ and $25 \%$ ), depending on the location of the dissection origin and its radiation. It starts suddenly and severely, which is quite opposite compared to the pain in myocardial infarction which frequently has the crescendo features, propagating towards the neck, jaw, and the back $(13,14)$.

In our patients, the demographics and the site of pain were typical, without electrocardiographic evidence of ischemia. This case has illustrated the importance of heart auscultation and echocardiography in the differential diagnosis of all patients presenting with chest pain.
The finding of a normal ECG and cardiac enzymes within normal range differ aortic dissection of acute myocardial infarction. Echocardiography, CT and MRI are non-invasive methods, which is considered the diagnostic gold standard for dissection.

Our patient was confirmed to have an acute aortic dissection throughout the whole length of aortic arch from the root to the truncusbrachocephalicus, along with the presence of the false lumen (diameter of the aorta $-60 \mathrm{~mm}$ ), aortic regurgitation (3-4+) and tricuspid regurgitation (2+). Unfortunately, the patient died due to progression of the course of the disease.

Several complications are associated with mortality in acute aortic syndrome, including sudden cardiovascular collapse, pericardial effusion, myocardial infarction, stroke and paralysis. Hypotension, which is present in the proximal dissection in up to $38 \%$ of cases, is most frequently caused by an acute heart insufficiency (due to acute aorta insufficiency) or is the consequence of hypovolemia caused by a rupture into the pericardium, intra-pleural or intra-peritoneal space (15).

If $\mathrm{AD}$ is suspected, the patient should be immediately transported to the center specially equipped for interventional procedures and cardiothoracic surgery interventions.

In the case of $\mathrm{AD}$ type $\mathrm{A}$, an urgent, immediate operation is indicated, using synthetic Dacron graft to replace part of the aorta to prevent blood flow into the false lumen. The lethal risk of the operation is about $20 \%$ (15).

\section{CONCLUSION}

Although aortic dissection is an uncommon entity, its outcome is frequently fatal and many patients with aortic dissection die before setting the diagnosis. This case illustrates the importance of aortic dissection as one of the differential diagnoses set in patients with symptoms of chest pain.

Echocardiography is essential for the diagnosis of aortic dissection, which raises the necessity of its application in emergency unit. 


\section{References}

1. Thomas T. Christoph A. Nienaber, et al . Acute Aortic Syndromes Circulation 2005; 112: 3802-13

2. Sampson UKA, Norman PE, Fowkes GR, et al. Global and regional burden of aortic dissection and aneurysms. Global Heart 2014; 8:171-80. http://dx.doi.org/10.1016/j.gheart.2013.12.010

3. Hagan PG, Nienaber CA, Isselbacher EM, et al. International Registry of Acute Aortic Dissection (IRAD): new insights from an old disease. JAMA 2000; 283: 897-903

http://dx.doi.org/10.1001/jama.283.7.897

4. Reul GJ, Cooley DA, Hallman GL, et al. Dissecting aneurysm of the descending aorta. Improved surgical results in 91 patients. Arch Surg 1975;110:632-40

http://dx.doi.org/10.1001/archsurg.1975.01360110 178030

5. Clouse WD, Hallett JW Jr, Schaff HV, et al. Acute aortic dissection: Population-based incidence compared with degenerative aortic aneurysm rupture. Mayo Clin Proc 2004;79:176-80

http://dx.doi.org/10.4065/79.2.176

6. Cigarroa JE, Isselbacher EM, DeSanctis RW, et al. Diagnostic imaging in the evaluation of suspected aortic dissection. Old standards and new directions. N Engl J Med 1993; 328:35-43. http://dx.doi.org/10.1056/NEJM199301073280107

7. Erbel R, Engberding R, Daniel $\mathrm{W}$, et al. Echocardiography in diagnosis of aortic dissection. Lancet 1989;1:457-61. http://dx.doi.org/10.1016/S0140-6736(89)91364-0

8. Nienaber CA, von Kodolitsch Y, Nicolas V, et al. The diagnosis of thoracic aortic dissection by noninvasive imaging procedures. N Engl J Med 1993;328: 1-9.

http://dx.doi.org/10.1056/NEJM199301073280101

9. Devereux RB, de Simone G, Arnett DK, Best LG, et al. Normal limits in relation to age, body size and gender of two-dimensional echocardiographic aortic root dimensions in persons $\geq 15$ years of age. Am J Cardiol 2012;110: 1189-94.

http://dx.doi.org/10.1016/j.amjcard.2012.05.063

10. Vriz O, Driussi C, Bettio M. et al. Aortic root dimensions and stiffness in healthy subjects. Am J Cardiol 2013;112:1224-29

http://dx.doi.org/10.1016/j.amjcard.2013.05.068

11. Olsson C, Thelin S, Stahle E, et al.Thoracic aortic aneurysm and dissection: increasing prevalence and improved outcomesreported in a nationwide population-based study of more than 14,000 cases from 1987 to 2002. Circulation 2006;114: 2611-8.

http://dx.doi.org/10.1161/CIRCULATIONAHA.1 06.630400

12. Howard DP, Banerjee A, Fairhead JF, et al. Population-based study of incidence and outcome of acute aortic dissection and premorbid risk factor control: 10-year results from the Oxford Vascular Study. Circulation 2013; 127:2031-7

http://dx.doi.org/10.1161/CIRCULATIONAHA.1 12.000483

13. Golledge J, Eagle K. Acute aortic dissection. Lancet 2008;372:55-66.

http://dx.doi.org/10.1016/S0140-6736(08)60994-0

14. Erbel R, Alfonso F, Boileau C et al. Diagnosis and management of aortic dissection. Eur Heat J 2001;22:1642-81

http://dx.doi.org/10.1053/euhj.2001.2782

15. Derek Juang, Alan C. Braverman,Kim Eagle, Aortic Dissection. Circulation. 2008; 118: e507-10 http://dx.doi.org/10.1161/CIRCULATIONAHA.1 08.799908 


\title{
Aortna disekcija - uloga ehokardiografije u Koronarnoj jedinici
}

\author{
Sanja Stojanović ${ }^{1}$, Marina Deljanin-Ilićc ${ }^{1,2}$, Stevan Ilić1,2, Bojan Ilić ${ }^{1}$, \\ Milovan Stojanović ${ }^{1}$, Dejan Petrović1,2 \\ ${ }^{1}$ Institut za lečenje i rehabilitaciju "Niška Banja" Niš, Srbija \\ ${ }^{2}$ Univerzitet u Nišu, Medicinski fakultet, Niš, Srbija
}

\section{SAŽETAK}

Aortna disekcija je retko, ali ozbiljno stanje, udruženo sa vrlo visokim moralitetom koje se manifestuje iznenadnim bolom u grudima i akutnom hemodinamskom nestabilnoću. Prezentovan je slučaj muškarca starog 64 godine sa disekcijom ushodne aorte i letalnim ishodom. Zdrav muškarac, bez istorije bolesti srca, iznenada je osetio akutni, razdirući bol u grudima koji se širio ka ledjima. Brzo postavljanje dijagnoze - idealno u roku od 1 jednog sata od manifestacije, auskultacija srca $i$ ehokardiografija čine ključni faktor u postavljanju dijagnoze aortne disekcije.

Ključne reči: akutni aortni sindrom, aortna disekcija, bol u grudima 